\title{
Species composition and population dynamics of malaria vectors in three previously ignored aquatic systems in Sri Lanka
}

Achini W. Fernando', Sevvandi Jayakody ${ }^{1 *}$, Hiranya K. Wijenayake ${ }^{1}$, Gawrie N. L. Galappaththy ${ }^{2}$, Mangala Yatawara ${ }^{3}$ and Jeevanie Harishchandra ${ }^{4}$

\begin{abstract}
Background: In 2015 alone there were an estimated 214 million new cases of malaria across the globe and 438,000 deaths were reported. Although indigenous malaria has not been reported in Sri Lanka since 2012, to date 247 imported cases of malaria have been identified. Knowledge of the locations, behaviour and vectorial capacity of potential malarial vectors is therefore needed to prevent future outbreaks. Attention is now being focused on some previously ignored habitats.
\end{abstract}

Methods: Active and abandoned granite and clay quarry pits, located in wet and intermediate zones, and agro wells located in the dry zone of Sri Lanka were mapped and sampled for 1 year, as potential mosquito breeding sites. Species composition and spatio-temporal variation in both malarial and other mosquito larvae were recorded.

Results: A total of 18 species of mosquito larvae were identified. Other than Anopheles culicifacies, the primary malaria vector, five species of potential malaria vectors (Anopheles vagus, Anopheles varuna, Anopheles nigerrimus, Anopheles peditaeniatus and Anopheles barbirostris) were found in all three aquatic systems. Additionally, Anopheles annularis was found in granite quarries and Anopheles subpictus and Anopheles pallidus in both types of quarry, but only during the initial sampling. Apart from potential malaria vectors, mosquito larvae such as Anopheles jamesii, Culex tritaeniorhynchus, Culex infula and Culex malayi were found in all three habitats at least once during the sampling period. Apart from potential malaria vectors and other mosquito larvae common to all three aquatic systems, Culex gelidus, Culex mimulus and Culex pseudo vishnui were detected in agro wells. Culex gelidus was also detected in granite quarry pits. Culex mimulus, Culex lutzia and Culex fuscocephala were detected in clay quarry pits. Accordingly, a total of 14, 13 and 15 mosquito species were identified in agro wells, granite and clay quarry pits, respectively.

Conclusions: Although zero occurrence of indigenous malaria has been achieved in Sri Lanka, the current study emphasizes the potential for future epidemics. The presence of native flora and fauna in abandoned granite and clay quarry pits and the need to extract drinking water from agro wells demand bio-sensitive control methods in these three aquatic systems.

Keywords: Agro well, Anopheline larvae, Clay quarry pit, Malaria, Granite quarry pit

\section{Background}

Globally, malaria has caused catastrophic and formidable health problems and about 3.2 billion people remain

\footnotetext{
*Correspondence: sevvandi_jayakody@yahoo.com

${ }^{1}$ Department of Aquaculture and Fisheries, Wayamba University of Sri Lanka, Makandura, Gonawila, Sri Lanka

Full list of author information is available at the end of the article
}

at risk [1]. At present, approximately $80 \%$ of malaria deaths are concentrated in just 15 countries, the majority of which are in Africa [1]. In Southeast Asia malaria is still prevalent in ten countries, with India, Indonesia and Myanmar accounting for $96 \%$ of cases [1]. The major Plasmodium species in this region are Plasmodium falciparum and Plasmodium vivax. However, the vector system in Southeast Asia is complex and difficult 
to distinguish morphologically, hence non-vectors have often been mistakenly included in potential malaria vector checklists [2].

In Sri Lanka, the traditional malaria-endemic zone extends across three-quarters of the country, encompassing most of the dry zone and intermediate zones [3]. About ten major epidemics have occurred there, while the epidemic between 1934 and 1935 was the most serious [4]. The Anti-Malaria Campaign (AMC) was established in 1911 and, since its inception, has made several attempts to eradicate indigenous malaria and to prevent transmission within the country [4]. Even though no indigenous malaria cases were recorded in 2013 [3] and 2014 [1], there is a potential for epidemics to occur [5], as imported malaria cases are still being recorded [6] and regulations for chemoprophylaxis and screening on re-entry to the country are not strictly adhered to [5].

Globally, malaria is declining [1, 7]. However, more effort is being made to understand the role of previously overlooked or ignored habitats in sustaining mosquito populations, as it has emerged that despite efforts to eliminate mosquitoes from known habitats, other habitats are harbouring populations which could cause malaria [8]. Additionally, new aquatic systems are constantly being created due to human activities, such as mining and agriculture. But these systems have not been given due attention despite their proximity to human dwellings and their increase in numbers. The current study was conducted in three previously ignored aquatic systems in Sri Lanka. Selection was based on proximity to human dwellings, relative abundance and presence of water during most months of the year, together with a lack of previous anopheline vector data. Accordingly, agro wells and granite and clay quarry pits were selected. Agro wells are abundant in the dry zone (mean annual rainfall $\geq 1750 \mathrm{~mm}$ ). They are intensively used by farmers for both agricultural and domestic purposes and are an integral part of any farmland in the dry zone of Sri Lanka. The diameter and depth of these wells can vary, depending on the location and depth of the ground water table. They are wide-mouthed and shallow. Granite and clay quarry pits are found in the wet (mean annual rainfall $\leq 2500 \mathrm{~mm}$ ), intermediate (mean annual rainfall $=1750-2500 \mathrm{~mm}$ ) and dry zones. They are present as both active and abandoned pits. The abandoned pits have become semi-naturalized, lentic water bodies and they now harbour a diversity of native flora and fauna. They are dynamic systems, with some of the abandoned quarries becoming active from time to time. This alters their connections, dimensions and resident aquatic organisms.

\section{Methods}

\section{Estimating the larval density of quarry pits}

Granite and clay quarry pits were selected in the wet and intermediate zones in the Ma oya River basin, which is the main production zone for granite and bricks in Sri Lanka. Initially all granite and clay quarry pits were mapped, using information extracted from Google Earth $^{\circledR}$, local people and government records. Between June and September 2011, the presence of mosquito larvae in these quarries was monitored using a 350-ml standard dipper, as described in 'Guidelines to searching for mosquito breeding habitats: stagnant water and conducting larval survey' [9].

From the initial survey, 41 clay quarry pits and 38 granite quarry pits were identified and their locations fixed using a hand-held GPS (GPS GAMIN-GPSMap60cs). Basic information about these mapped pits is given in Fig. 1a-d. No mosquitoes were detected in 38 and $24 \%$ of clay and granite quarry pits, respectively. Of the 41 clay quarry pits, 38 were abandoned and of the 38 granite quarry pits, 33 were abandoned. All abandoned quarries appeared to be naturalized by native flora and fauna. From the abandoned quarries, ten with evidence of mosquito larvae presence were randomly selected for continuous monitoring of anopheline vectors and other mosquitoes, from February 2012 to June 2013.

In order to measure the larval density, a dipper was lowered gently at an angle of $45^{\circ}$ to just below the surface, to ensure an undisturbed and uninterrupted flow of water, and 350-ml was collected with any larvae that might be present. Six dips per sampling position were made and the samples were pooled. Sampling positions were always $10 \mathrm{~m}$ apart and the number of sampling positions varied according to the size of the quarry. The depth of each sampling position was recorded, to the nearest $\mathrm{cm}$, using the graduated handle of the dipper. The prevailing weather conditions (cloud cover, wind direction, rain), water turbidity and water temperature were also recorded for each quarry sampled. Sampling was always carried out between 08:00 and 14:00.

\section{Estimating the larval density of agro wells}

An area with a known history of malaria outbreaks was selected from North Central province. Accordingly, 132 agro wells were identified and marked and sampled for mosquitoes in Wagollakada and Rathmale. Basic information about these agro wells is given in Fig. 1e, f. No mosquitoes were found in $66 \%$ of the wells. Of the wells with mosquitoes, 36 were randomly selected for continuous monitoring. Buckets were used to draw 2-1 samples of water from four sides of each well, with minimal disturbance to the water and any mosquito larvae present. 


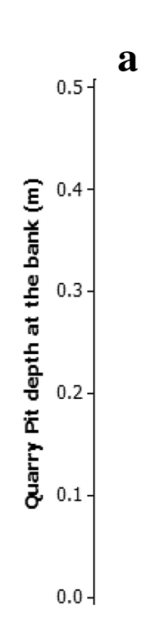

c
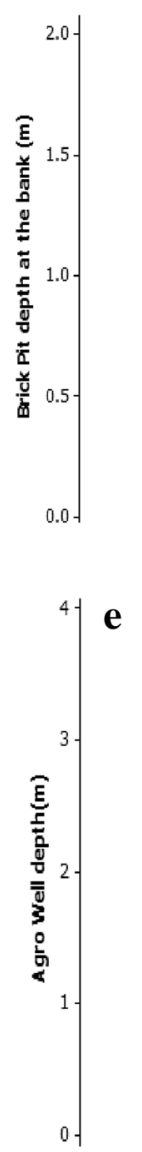
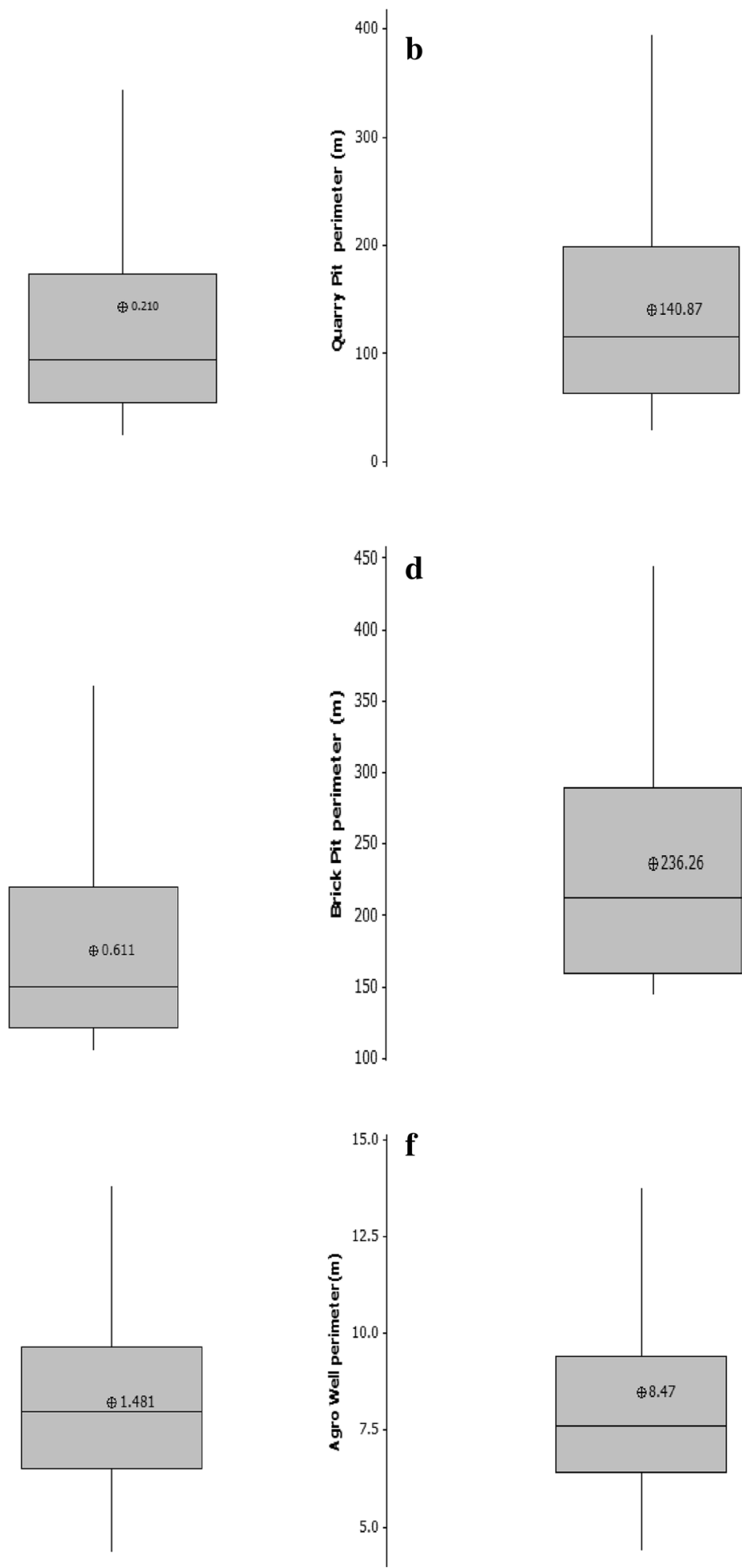

Fig. 1 Box plots depicting mean depth and perimeter of granite quarry pits $\mathbf{a}, \mathbf{b}$, clay quarry pits $\mathbf{c}$, $\mathbf{d}$ and agro wells $\mathbf{e}$, $\mathbf{f}$ during the initial survey

Once the larvae had been collected, they were transferred to labelled vials. In the laboratory, the species of third and fourth instar larvae were identified using standard guides [10]. The numbers of larvae per dip were then estimated and mean values for each granite and clay pit and for each month were calculated. 


\section{Ethical committee}

The Ethics Committee of Wayamba University of Sri Lanka in the Faculty of Livestock, Fisheries and Nutrition gave approval for this study, including the collection of mosquito larvae from aquatic systems for identification.

\section{Results}

Occurrence of difference anopheline and culicine larvae in granite and clay quarry pits and agro wells

A total of 18 species of mosquito larvae were identified in the current study. Other than Anopheles culicifacies, the primary malaria vector, five species of potential malaria vectors (Anopheles vagus, Anopheles varuna, Anopheles nigerrimus, Anopheles peditaeniatus and Anopheles barbirostris) were also identified in all three aquatic systems. Additionally, Anopheles annularis was found in granite quarries and Anopheles subpictus and Anopheles pallidus in both types of quarries, but only during the initial sampling.

Apart from potential malaria vectors, mosquito larvae such as Anopheles jamesii, Culex tritaeniorhynchus, Culex infula and Culex malayi were present in all three aquatic systems at least once during the sampling period.

Besides the potential malaria vectors and other mosquito larvae common to all three aquatic systems, Culex gelidus, Culex mimulus and Culex pseudo vishnui were detected in agro wells. $C x$. gelidus was also detected in granite quarry pits and $C x$. mimulus, Culex lutzia and Culex fuscocephala were detected in clay quarry pits. Accordingly, a total of 13, 15 and 14 mosquito species were identified in granite and clay quarry pits and agro wells, respectively (Fig. 2).

\section{Fluctuation of larval density in granite quarry pits}

In granite quarry pits, at least one species of mosquito was detected at every sampling and a total of eight potential malaria vectors (An. culicifacies, An. varuna, An. peditaeniatus, An. nigerrimus, An. vagus, An. barbirostris, An. pallidus, An. annularis) were recorded (Table 1). The peak densities of all mosquitoes $(\bar{x}=0.61 \pm 0.72$ SD per dip) and potential malaria vectors $(\bar{x}=0.542 \pm 0.675 \mathrm{SD}$ per dip) were recorded in January 2013 (Fig. 3). Table 1 lists the species-specific population fluctuations for different months, showing that granite quarry pits served as a breeding site for at least one species of potential malaria vector throughout the study period (Fig. 3b).

\section{Fluctuation of larval density in clay quarry pits}

During the study period a total of 14 mosquito species, of which seven were potential malaria vectors (An. culicifacies, An. vagus, An. varuna, An. nigerrimus, An. peditaeniatus, An. barbirostris, An. subpictus), were recorded in clay quarry pits (Table 2). The peak densities of all mosquitoes $(\bar{x}=0.87 \pm 1.20 \mathrm{SD}$ per dip) and potential malaria vectors $(\bar{x}=0.724 \pm 1.192 \mathrm{SD}$ per dip) were recorded in March 2012 (Table 2). Clay quarry pits also served as breeding sites throughout the sampling period (Fig. 4).

\section{Fluctuation of larval density in agro wells}

A total of 14 mosquito species, of which seven were potential malaria vectors (An. culicifacies, $A n$. vagus, $A n$. varuna, An. nigerrimus, An. peditaeniatus, An.subpictus, An. barbirostris), were also recorded in agro wells (Table 3$)$. The peak mosquito densities of all mosquitoes $(\bar{x}=0.2 \pm 0.58$ SD per dip) (Fig. 5 a) and potential malaria vectors $(\bar{x}=0.017 \pm 0.40 \mathrm{SD}$ per dip) were recorded in March 2012 (Fig. 5 b). The density of the primary malaria vector An. culicifacies peaked in October 2012 (0.02 \pm 0.15 SD per dip).

\section{Discussion}

This study revealed the challenges in totally eradicating malaria, when existing aquatic systems are harbouring several species of potential malaria vectors. At a time when the Anti Malaria Campaign has declared Sri Lanka free from indigenous malaria [7], a thorough understanding of potential breeding sites is essential. The AMC achieved almost complete eradication of malaria from Sri Lanka in 1963, through a very effective integrated vector management programme, entomological surveys, indoor residual spraying, and prophylaxis [4]. However, between 1967 and 1968 the country faced another malaria epidemic $[4,11,12]$. Discontinuation of the vector management programme led to this resurgence of malaria, which is now considered to be a classical example of a post-eradication epidemic [12]. Although no indigenous malaria cases have been reported since 2012, a total of 95, 46 and 36 imported malaria cases were reported in 2013, 2014 and 2015, respectively [1, 5, 13]. Malaria is mainly imported by workers returning from Africa and other Southeast Asian countries [14], pilgrims returning from India $[14,15]$, legal and illegal emigrants from Africa [6], soldiers returning from foreign missions [15] and even multiday boat fishermen [13]. The three aquatic systems investigated in this study exist in close proximity to human dwellings, especially the agro wells. Accordingly, the probability of an epidemic cannot be ruled out.

There are other examples of malaria recurring after total eradication, such as in Mauritius, where malaria was reported in 1975 after total eradication in 1969 [16]. Therefore, any country that has achieved total eradication of indigenous malaria should still focus on factors that could lead to a recurrence of the disease. As long as mosquito vectors are present, with suitable climatic conditions and as long as malaria is still being imported, 


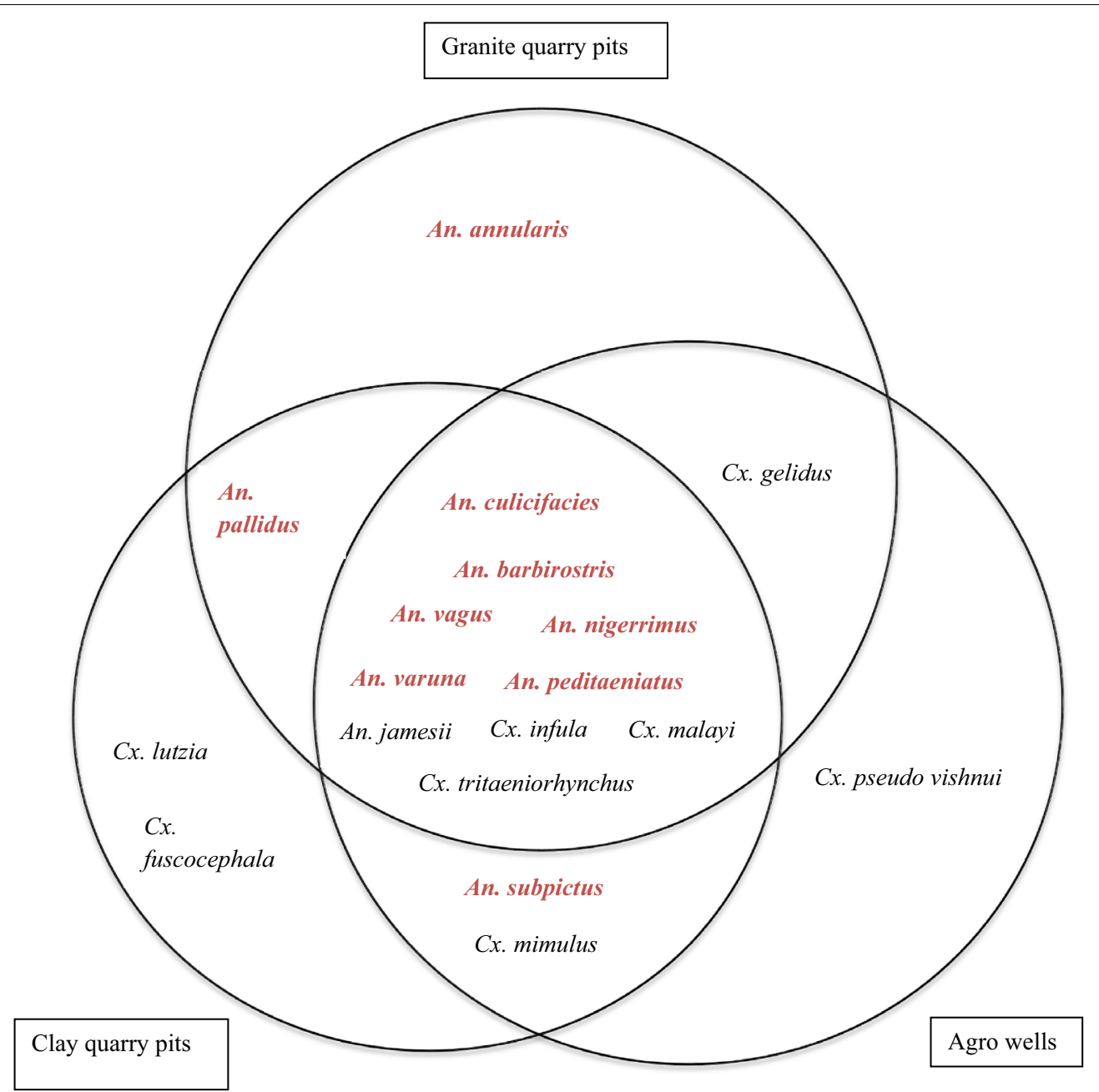

Fig. 2 Species composition of mosquitoes recorded from granite quarry pits, clay quarry pits and agro wells. Potential malaria vectors are indicated in bold red letters

Table 1 Summary of the larval density fluctuation from February 2012 to January 2013 in granite quarry pits

\begin{tabular}{|c|c|c|}
\hline Species & Months of detection & Peak density $(\bar{x} \pm$ SD per dip $)$ \\
\hline An. culicifacies & February 2012 to January 2013 & January $2013(0.13 \pm 0.28)$ \\
\hline An. vagus & March, April and August 2012 & March $2012(0.05 \pm 0.09)$ \\
\hline An. varuna & February to September 2012 and January 2013 & September $2012(0.09 \pm 0.15)$ \\
\hline An. nigerrimus & February to September 2012 and January 2013 & January $2013(0.07 \pm 0.19)$ \\
\hline An. peditaeniatus & February 2012 to January 2013 & May $2012(0.28 \pm 0.30)$ \\
\hline An. barbirostris & February to December 2012 and January 2013 & December $2012(0.47 \pm 0.25)$ \\
\hline An.jamesii & March 2012 to January 2013 & March $2012(0.07 \pm 0.15)$ \\
\hline Cx. tritaeniorhynchus & $\begin{array}{l}\text { February, March, May, August, September, } \\
\text { October } 2012 \text { and January } 2013\end{array}$ & December 2012 (0.12 \pm 0.22) \\
\hline Cx. infula & August and September 2012 & September $2012(0.02 \pm 0.07)$ \\
\hline Cx. gelidus & March, July and September 2012 & March $2012(0.08 \pm 0.26)$ \\
\hline Cx.malayi & December 2012 & December $2012(0.21 \pm 0.57)$ \\
\hline Potential malaria vector larvae & February 2012 to January 2013 & January $2013(0.54 \pm 0.67)$ \\
\hline Total anopheline and culicine mosquito larvae & February 2012 to January 2013 & January $2013(0.61 \pm 0.72)$ \\
\hline
\end{tabular}

Potential malaria vectors are given in bold text 

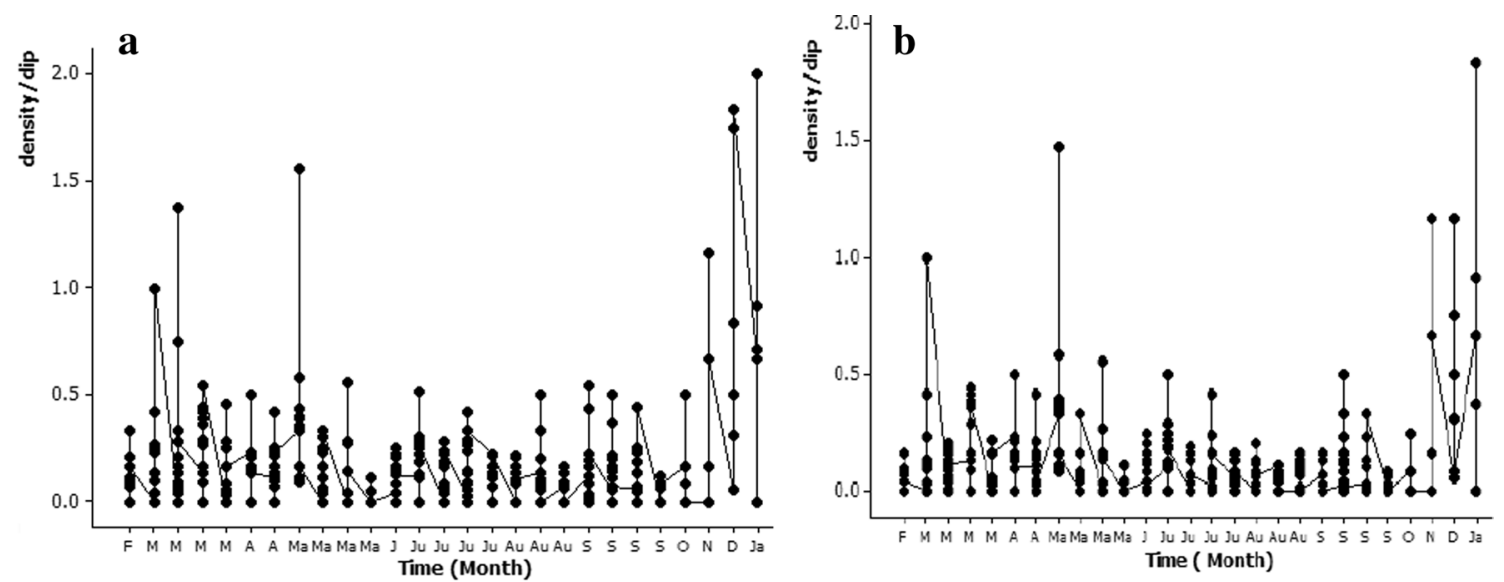

Fig. 3 Fluctuation of larval density of $\mathbf{a}$ total anopheline and culicine, and $\mathbf{b}$ all potential malaria vector species from February 2012 to January 2013 in granite quarry pits

Table 2 Summary of the larval density fluctuation from February 2012 to January 2013 in clay quarry pits

\begin{tabular}{|c|c|c|}
\hline Species & Months of detection & Peak density $(\bar{x} \pm$ SD per dip $)$ \\
\hline An. culicifacies & February, March, June, July and August 2012 & March $2012(0.37 \pm 1.17)$ \\
\hline An. vagus & March and September 2012 & March $2012(0.11 \pm 0.31)$ \\
\hline An. varuna & March to July 2012, August and September 2012, May 2013 & August $2012(0.23 \pm 0.48)$ \\
\hline An. subpictus & August and October 2012 & August $2012(0.28 \pm 0.79)$ \\
\hline An. nigerrimus & February to October 2012 & August $2012(0.19 \pm 0.53)$ \\
\hline An. peditaeniatus & February to October 2012 & May $2012(0.34 \pm 0.37)$ \\
\hline An. barbirostris & March to December 2012 & September $2012(0.30 \pm 0.45)$ \\
\hline An. jamesii & February to October 2012 & May $2012(0.40 \pm 0.34)$ \\
\hline Cx. tritaeniorhynchus & March, May, July, August, September and October 2012 & August $2012(0.22 \pm 0.42)$ \\
\hline Cx. infula & March 2012 & March $2012(0.06 \pm 0.16)$ \\
\hline Cx.mimulus & February 2012 & February $2012(0.06 \pm 0.25)$ \\
\hline Cx.malayi & February and December 2012 & February $2012(0.12 \pm 0.50)$ \\
\hline Cx. lutzia & March to June and August 2012 & August $2012(0.08 \pm 0.18)$ \\
\hline Cx. fuscocephala & March, May and June 2012 & May $2012(0.04 \pm 0.11)$ \\
\hline Potential malaria vector larvae & February to December 2012 & March $2012(0.72 \pm 1.19)$ \\
\hline Total anopheline and culicine mosquito larvae & February to December 2012 & March $2012(0.87 \pm 1.20)$ \\
\hline
\end{tabular}

Potential malaria vectors are given in bold text

there is potential for further epidemics [13]. Notably, the results of the current study indicated that most of the potential malaria vectors that were found are present throughout the year in all three aquatic systems. Additionally, potential malaria vector species recorded in this study have also been recorded in marshlands [8], tanks $[8,17]$, streams $[8,18,19]$, rice fields $[8,17]$, reservoirs $[8,20]$, seepage areas [17], irrigation canals $[8,17$, $18,21]$, agro wells [8], temporary water pools [8], brick fields [22], quarries [22], puddles [22], abandoned pits [23], animal foot prints [8], and wastewater and rainwater bodies [8]. Hence, the current study highlights the challenges to maintaining an indigenous malaria-free status.
All three of the aquatic systems studied, as well as many of the habitats listed above, exist in close proximity to human dwellings, especially the agro wells. As an island nation, Sri Lanka's capacity to minimize trans-boundary disease transmission is limited. Hence, the AMC should expect imported cases of malaria to continue in future. However, the AMC have several options for eradicating the resident vector populations, irrespective of the threat from neighbouring countries.

Of the three aquatic systems studied, agro wells are of primary concern, as they are present in the previous malaria belt of the country and are found within most properties. Their numbers are steadily increasing, 

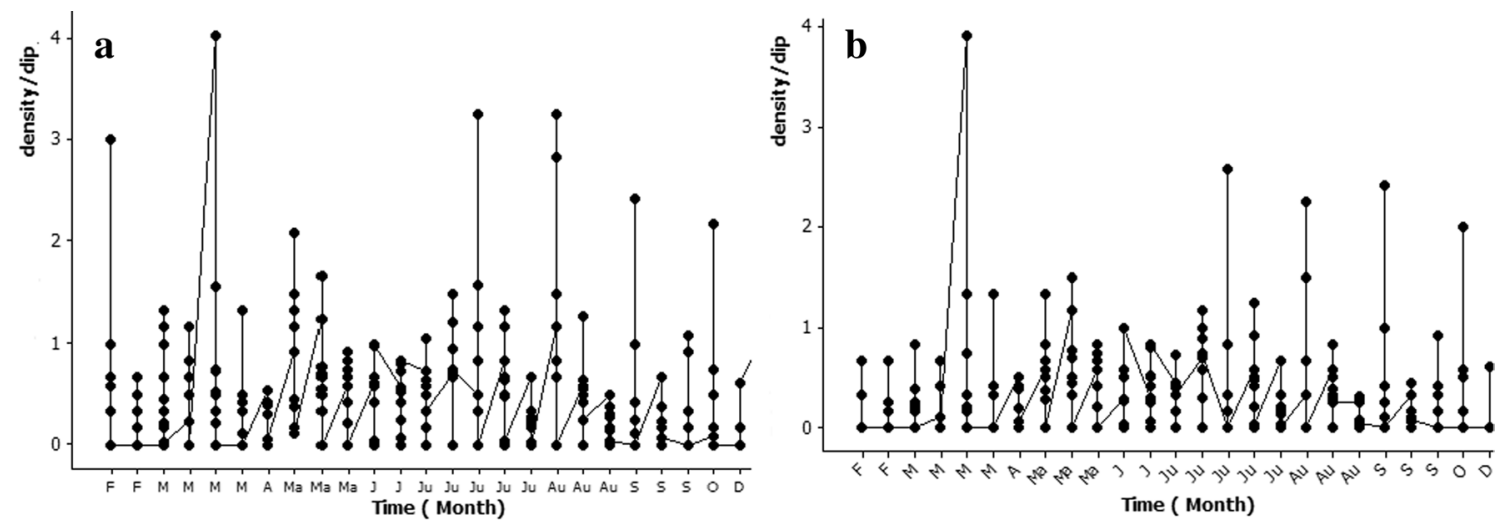

Fig. 4 Fluctuation of larval density of $\mathbf{a}$ total anopheline and culicine, and $\mathbf{b}$ all potential malaria vector species from February 2012 to December 2012 in clay quarry pits

Table 3 Summary of the larval density fluctuation from February 2012 to January 2013 in agro wells

\begin{tabular}{|c|c|c|}
\hline Species & Months of detection & $\begin{array}{l}\text { Peak density } \\
(\bar{x} \pm \text { SD per dip })\end{array}$ \\
\hline An. culicifacies & $\begin{array}{l}\text { March, April, May, June, August to November } 2012 \\
\text { and February, June } 2013\end{array}$ & October $2012(0.02 \pm 0.15)$ \\
\hline An. vagus & May, June, November 2012 and June 2013 & June $2012(0.000965 \pm 0.01)$ \\
\hline An. subpictus & April, May, June and July 2012 & June $2012(0.000965 \pm 0.01)$ \\
\hline An. varuna & February to June, September 2012 and February 2013 & May, November $2012(0.013 \pm 0.05)$ \\
\hline An. nigerrimus & February to May 2012 and February and June 2013 & February $2013(0.018 \pm 0.12)$ \\
\hline An. barbirostris & February to August, November 2012 and June 2013 & March $2012(0.062 \pm 0.33)$ \\
\hline An. peditaeniatus & May 2012, February and June 2013 & February $2013(0.0013 \pm 0.017)$ \\
\hline An. jamesii & March 2012 and June 2013 & March $2012(0.001 \pm 0.01)$ \\
\hline Cx. tritaeniorhynchus & $\begin{array}{l}\text { February to May, August, September 2012, February } \\
\text { and June } 2013\end{array}$ & May $2012(0.029 \pm 0.12)$ \\
\hline Cx. gelidus & April 2012 & April $2012(0.001 \pm 0.01)$ \\
\hline Cx. infula & February to June 2012 & March and May $2012(0.0062 \pm 0.04)$ \\
\hline Cx. mimulus & March to June 2012 & April $2012(0.036 \pm 0.25)$ \\
\hline CX.malayi & March to May 2012 & May $(0.009 \pm 0.09)$ \\
\hline Cx.pseudo vishnui & March 2012 & March $2012(0.00008 \pm 0.001)$ \\
\hline Potential malaria vector larvae & February 2012 to June 2013 & March $2012(0.017 \pm 0.40)$ \\
\hline Total anopheline and culicine mosquito larvae & February 2012 to June 2013 & March $2012(0.20 \pm 0.58)$ \\
\hline
\end{tabular}

Potential malaria vectors are given in bold text

although the number present in the North Central Province is not known. However, the published literature mentions that over 50,000 agro wells were constructed between 1980 and 1990 [24] Agro wells are used for obtaining drinking water in many households, which prevents the application of conventional chemical control methods. At present people also stock fish in agro wells, mainly Aplocheilus parvus, Poecilia reticulata, Anabas testudineus, Oreochromis, and Channa spp., as a means of biological control of mosquito larvae. It is therefore vital to continue studying the use of biological agents, especially the potential of native species [25]. Physical methods such as landfill and levelling, cleaning and water management [17] have limited use, as semi-naturalized quarries cannot be overly modified due to a requirement to maintain species diversity. Nevertheless, guidelines given at the point of granting excavation rights clearly indicate the need to refill pits after use, and if those guidelines are followed, any further abandonment of pits could be avoided.

At present, biological control of vectors and continuous monitoring of the three systems studied are recommended. The options for controlling mosquitoes in these aquatic systems include maintaining ecological integrity, 

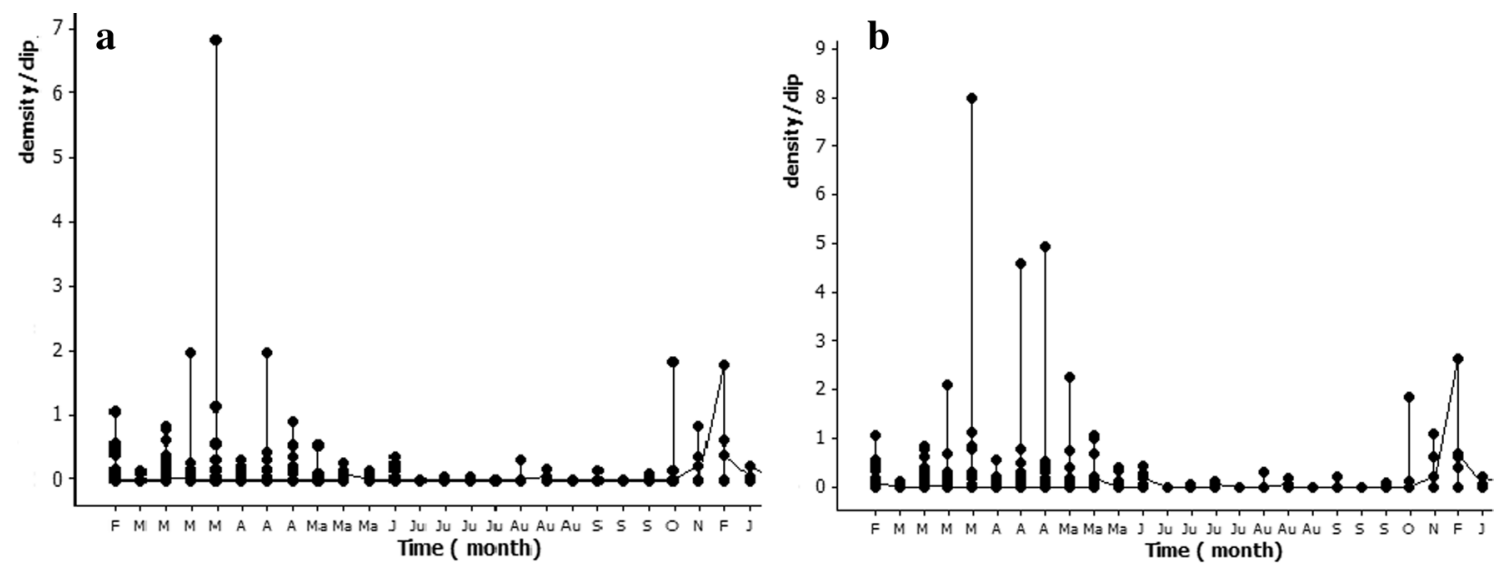

Fig. 5 Fluctuation of larval density of a total anopheline and culicine, and $\mathbf{b}$ all potential malaria vector species from February 2012 to June 2013 in agro wells

so that natural predators control mosquito populations, the introduction of larvivorous fish $[26,27]$ or other natural predators [28-31] and testing of target-specific biopesticides [32, 33]. At the same time, the general public should be encouraged to use mosquito nets and medical practitioners should be provided with facilities for screening immigrants coming from destinations where malaria is suspected to exist.

\section{Conclusions}

The presence of native flora and fauna in abandoned pits and the need to extract drinking water from agro wells demand alternative control methods in these three aquatic systems. Although eradication of indigenous malaria has been achieved in Sri Lanka, these previously unexplored habitats have potential for causing epidemics in the future, unless their malariogenetic potential is curtailed.

\section{Authors' contributions}

SJ designed the study protocol and supervised field and laboratory tests throughout the study period. SJ, HKW, AWF, and JH carried out the fieldwork. AWF drafted the manuscript and SJ, GNLG and HKW corrected it. HKW, JH, MY, and GNLG made important suggestions for the experiment throughout the study period. All authors read and approved the final manuscript.

\section{Author details}

${ }^{1}$ Department of Aquaculture and Fisheries, Wayamba University of Sri Lanka, Makandura, Gonawila, Sri Lanka. ${ }^{2}$ World Health Organization, Yangon, Myanmar. ${ }^{3}$ Department of Zoology and Environmental Management, University of Kelaniya, Kelaniya, Sri Lanka. ${ }^{4}$ Anti Malaria Campaign, Colombo 05, Sri Lanka.

\section{Acknowledgements}

The study was carried out as a part of a research project funded by the Global Fund to Fight AIDs, Tuberculosis and Malaria (GFATM). Mr. Ravindra Jayanetti and Dr. Devika Perera, regional heads of AMC in North Central and North Western provinces are acknowledged for assistance with species identification and provision regional teams for fieldwork. The assistance of AMC entomological teams from the Northwestern, North Central and Western provinces are acknowledged for their support in the field and identification of larvae. Ms. Nirosha Liyanage is acknowledged for her assistance with Arc GIS.

\section{Competing interests}

The authors declare that they have no competing interests.

Received: 3 February 2016 Accepted: 27 April 2016

Published online: 10 May 2016

\section{References}

1. WHO. World Malaria Report 2015. Geneva: World Health Organization; 2015. http://apps.who.int/iris/bitstream/10665/200018/1/9789241565158_eng. pdf?ua $=1$.

2. Suwonkerd W, Ritthison W, Ngo CT, Tainchum K, Bangs MJ, Chareonviriyaphap T. Vector biology and malaria transmission in Southeast Asia in Anopheles mosquitoes-new insights into malaria vectors, Manguin S editor. 2013. http://cdn.intechopen.com/pdfs-wm/45385.pdf.

3. Karunaweera ND, Galappaththy GNL, Wirth DF. On the road to eliminate malaria in Sri Lanka: lessons from history, challenges, gaps in knowledge and research needs. Malar J. 2014;13:59-68. http://www.malariajournal. com/content/13/1/59.

4. Konradsen F, Amerasinghe FP, van der Hoek W, Amerasinghe PH. Malaria in Sri Lanka. Current knowledge on transmission and control. Colombo: International Water Management Institute. 2000. https://core.ac.uk/ download/files/153/6405335.pdf.

5. Fernando SD, Dharmawardana P, Semege S, Epasinghe G, Senanayake N, Rodrigo C, et al. The risk of imported malaria in security forces personnel returning from overseas missions in the context of prevention of re-introduction of malaria to Sri Lanka. Malar J. 2016;15:144. http://malariajournal.biomedcentral.com/articles/10.1186/s12936-016-1204-y.

6. Wickramage K, Premaratne RG, Peiris SL, Mosca D. High attack rate for malaria through irregular migration routes to a country on verge of elimination. Malar J. 2013;12:276. http://link.springer.com/article/10.1186/1475-2875-12-276/fulltext.html.

7. WHO. World Malaria Report 2014. Geneva: World Health Organization. 2014. http://www.who.int/malaria/publications/world_malaria_ report_2014/wmr-2014-no-profiles.pdf.

8. Gunathilaka N, Fernando T, Hapugoda M, Wickremasinghe R, Wijeyerathne P, Abeyewickreme W. Anopheles culicifacies breeding in polluted water bodies in Trincomalee District of Sri Lanka. Malar J. 2013;12:285. http://malariajournal.biomedcentral.com/ articles/10.1186/1475-2875-12-285.

9. Anon. Guidelines to searching for mosquto breeding habitats (Stagnant Water) and conducting larval survey. Urban Malaria Control Programme. 2005. http:// www.biomedcentral.com/content/supplementary/1475-2875-7-20-s2.pdf.

10. Amerasinghe FP. A guide to the identification of the anopheline mosquitoes (Diptera: Culicidae) of Sri Lanka. Cey J Sci (Bio Sci). 1992. http://dl.nsf. 
ac.lk/bitstream/handle/1/7757/CJS\%28B.S\%29-22\%281\%29-1.pdf?seque nce $=2 \&$ is Allowed $=y$.

11. Premaratna R, Galappaththy G, Chandrasena N, Fernando R, Nawasiwatte $T$, de Silva $N R$, et al. What clinicians who practice in countries reaching malaria elimination should be aware of: lessons learnt from recent experience in Sri Lanka. Malar J. 2011;10:302. http://malariajournal.biomedcentral.com/articles/10.1186/1475-2875-10-302.

12. Najera JA, Kouznetzsov RL, Delacollette C. Malaria epidemics, detection and control, forecasting and prevention. Geneva: World Health Organization. 1998. http://www.who.int/malaria/publications/atoz/ whomal981084/en/.

13. Dharmawardena P, Premaratne RG, Kumudunayana WM, Gunasekera TDAW. Characterization of imported malaria, the largest threat to sustained malaria elimination from Sri Lanka. Malar J. 2015;14:144. https:// malariajournal.biomedcentral.com/articles/10.1186/s12936-015-0697-0.

14. Premaratne R, Ortega L, Janakan N, Mendis KN. Malaria elimination in Sri Lanka: what it would take to reach the goal. WHO South-East Asia J Public Health. 2014;3:85-89. Available from: http://www.searo.who.int/publications/journals/seajph/seajphv3n1 p87.pdf.

15. Galappaththy GNL, Fernando SD, Abeyasinghe RR. Imported malaria: A possible threat to the elimination of malaria from Sri Lanka?. Trop Med Int Health. 2013;18:761-768. http://www.ncbi.nlm.nih.gov/ pubmed/23506152.

16. Gueye CS, Sanders KC, Galappaththy GNL, Rundi C, Tobgay T, Sovannaroth S, et al. Active case detection for malaria elimination: a survey among Asia Pacific countries. Malar J. 2013;12:358. http://globalhealthsciences.ucsfedu/sites/default/files/content/ghg/mei-sandersetal-2012-a-confusion-of-acronyms.pdf.

17. Yasuoka J, Levins R, Mangione TW, Spielman A. Community-based rice ecosystem management for suppressing vector anophelines in Sri Lanka. Trans R Soc Trop Med Hyg. 2006;100:995-1006. http://www.sciencedirect. com/science/article/pii/S0035920306000770.

18. Konradsen F, van der Hoek W, Amerasinghe FP, Mutero C, Boelee E. Engineering and malaria control: Learning from the past 100 years. Acta Trop. 89. 2004;2:99-108. https://www.researchgate.net/profile/Flemming_Konradsen/publication/8912650_Engineering_and_malaria_control_Learning_from_the_past_100_years/links/55b218d908ae9289a084ffb2.pdf.

19. van der Hoek W, Konradsen F, Amerasinghe PH, Perera D, Piyaratne MK, Amerasinghe FP. Towards a risk map of malaria for Sri Lanka: The importance of house location relative to vector breeding sites. Int J Epidemiol. 2003;2:280-5. http://ije.oxfordjournals.org/content/32/2/280. full.pdf+html.

20. Kusumawathie PHD, Wickremasinghe AR, Karunaweera ND, Wijeyaratne MJS, Yapabandara AMGM. Anopheline breeding in river bed pools below major dams in Sri Lanka. Acta Trop. 2006;99:30-3. http://www.sciencedirect.com/science/article/pii/S0001706X06001082.

21. Amerasinghe FP, Priyani $H$, Amarasinghe JS, Peris M, Wirtz RA. Anopheline ecology and malaria infection during the irrigation development of an area of the Mahaweli Project, Sri Lanka. Am J Trop Med Hyg. 1991;45:22635. http://www.mosquitocatalog.org/files/pdfs/002600-7.pdf.

22. Wickramasinghe M. Malaria and its control in Sri Lanka. Ceylon Med J. 1981;26:107-15. http://www.cabdirect.org/abstracts/19832900748.html.

23. Yapabandara AMGM, Curtis CF, Wickramasinghe MB, Fernando WP. Control of malaria vectors with the insect growth regulator pyriproxyfen in a gem mining area of Sri Lanka. Acta Trop. 2001;80:265-76. http://www. sciencedirect.com/science/article/pii/S0001706X01001784.

24. Jayakody AN. Large Diameter Shallow Agro-Wells - a national asset or a burden for the nation?. J Agric Sci. 2006;2:1-10. http://192.248.87.13/journal_agri/papers/agri_vol2_1_2006/agri_vol2_1_2006_article1.pdf.

25. Fernando GKAW, Jayakody S, Wijenayake WMHK, Galappaththy GNL, Yatawara M, Harishchandra RDJ, et al. Diurnal variation in the feeding patterns and food preferences of Dwarf panchax (Aplocheilus parvus). Sri Lanka J Aquat Sci. 2015;20:19-29. http://sljas.sljol.info/articles/abstract/10.4038/ sljas.v20i2.7475/.

26. Ghosh SK, Tiwari SN, Sathyanarayan TS, Sampath TRR, Sharma VP, Nanda $\mathrm{N}$, et al. Larvivorous fish in wells target the malaria vector sibling species of the Anopheles culicifacies complex in villages in Karnataka, India. Trans R Soc Trop Med Hyg. 2005;99:101-5. http://trstmh.oxfordjournals.org/ content/99/2/101.short.

27. Kant R, Haq S, Srivastava HC, Sharma VP. Review of the bioenvironmental methods for malaria control with special reference to the use of larvivorous fishes and composite fish culture in central Gujarat. India. J Vector Borne Dis. 2013;50:1-12. https://www.researchgate.net/profile/Dr_Srivastava/publication/236908396 Review of the bioenvironmental methods_for_malaria_control_with_special_reference_to_the_use_of_larvivorous_fishes_and_composite_fish_culture_in_central_Gujarat_India/ links/00b7d539020514d97c000000.pdf.

28. Kweka EJ, Zhou G, lii TMG, Afrane Y, Nyindo M, Githeko AK, et al. Predation efficiency of Anopheles gambiae larvae by aquatic predators in western Kenya highlands. Parasit Vectors. 2011:4:128-134. http://parasitesandvectors.biomedcentral.com/articles/10.1186/1756-3305-4-128.

29. Collins LE, Blackwell A. The biology of Toxorhynchites mosquitoes and their potential as biocontrol agents. Biocontrol News Inf. 2000;4:105116. https://www.researchgate.net/profile/Larissa_Collins/publication/216675054_The_biology_of_Toxorhynchites_mosquitoes_and_ their_potential_as_biocontrol_agents/links/0c960521635713fa59000000. pdf.

30. Aditya G, Bhattacharyya S, Kundu N, Saha GK. Frequency-dependent prey-selection of predacious water bugs on Armigeres subalbatus immatures. J Vector Borne Dis. 2005;42:9-14. http://mrcindia.org/journal/ issues/421009.pdf.

31. Kumar R, Hwang JS. Larvicidal efficiency of aquatic predators: a perspective for mosquito biocontrol. Zool Stud. 2006;45:447-466. https://www. researchgate.net/profile/Ram_Kumar65/publication/228388596_Larvicidal_efficiency_of_aquatic_predators_A_perspective_for_mosquito_ biocontrol/links/0912f50699e4023be0000000.pdf.

32. Lacey LA, Merritt RW. The safety of bacterial microbial agents of bacterial microbial agents used for black fly and mosquito control in aquatic environments. Environ Impacts Microb Insectic. 2003;1:151-168. http://www. wnv.wsu.edu/referencematerial/pdf/microbial\%20mosquito\%20control. pdf.

33. Thomas MB, Read AF. Can fungal biopesticides control malaria?. Nat Rev Microbiol. 2007;5:377-83. http://www.nature.com/nrmicro/journal/v5/ n5/abs/nrmicro1638.html.

\section{Submit your next manuscript to BioMed Central and we will help you at every step:}

- We accept pre-submission inquiries

- Our selector tool helps you to find the most relevant journal

- We provide round the clock customer support

- Convenient online submission

- Thorough peer review

- Inclusion in PubMed and all major indexing services

- Maximum visibility for your research

Submit your manuscript at www.biomedcentral.com/submit
() BioMed Central 